\title{
Editorial
}

\section{Coloniality, neoliberalism and the Anthropocene}

In only a relatively short span of planetary time humans have emerged as the dominant species on Earth. This dominance has occurred through a remarkably effective transformative process that propelled humanity from being only a few localized dwellers foraging for food and living in makeshift shelters, to a global population of approximately 7.5 billion people inhabiting virtually every corner of the Earth; ${ }^{1}$ all fighting, with variously different degrees of relentless tenacity, for survival amidst increasingly limited resources that sustain life. ${ }^{2}$

While we are still officially in the Holocene epoch (its third and most recent age was recently confirmed as the Late Holocene Meghalayan Age), ${ }^{3}$ geologists now suggest (not altogether uncontroversially), ${ }^{4}$ that we might be entering the Anthropocene; a new human-dominated geological epoch in which Earth's carrying capacity is being breached in a time characterized by profound and increasing uncertainty: ${ }^{5}$

It takes no stretch of the imagination to see that the human species is now an agent of change of geologic proportions. We literally move mountains to mine the earth's minerals, redirect rivers to build cities in the desert, torch forests to make way for crops and cattle, and alter the chemistry of the atmosphere in disposing of our wastes. At humanity's hand, the earth is undergoing a profound transformation - one with consequences we cannot fully grasp. ${ }^{6}$

Of all the many drivers that have contributed, and continue to contribute, to the Anthropocene's signatures, two stand out as being particularly troubling: coloniality and neoliberalism.

There is little disputing the suggestion that industrialisation - the origins of the Anthropocene on the dominant account - was fundamentally capitalist in ambition

1. <http://theconversation.com/7-5-billion-and-counting-how-many-humans-can-the-earthsupport-98797>.

2. K Arrow et al., 'Economic Growth, Carrying Capacity, and the Environment' (1995) 268 Science 520-21.

3. International Commission on Stratigraphy, 'Collapse of Civilizations Worldwide Defines Youngest Unit of the Geologic Time Scale'. Available at <http://www.stratigraphy.org/index. php/ics-news-and-meetings/119-collapse-of-civilizations-worldwide-defines-youngest-unit-ofthe-geologic-time-scale>.

4. See, for example, J Barber, Disciplinarity, Epistemic Friction and the 'Anthropocene' (PhD Thesis, University of Edinburgh, Edinburgh, 2018); A Malm and A Hornborg, 'The Geology of Mankind? A Critique of the Anthropocene Narrative' (2014) 1(1) Anthropocene Review 62-9.

5. J Zalasiewicz et al., 'The Working Group on the Anthropocene: Summary of Evidence and Interim Recommendations' (2017) 19 Anthropocene 55-60.

6. S Postel, 'Carrying Capacity: Earth's Bottom Line' (1994) Challenge 4-12 at 4. 
and motivation - and inseparable from European (especially British) colonialism'. ${ }^{7}$ Intensified, as it now is by the philosophy of neoliberalism, colonialism has been (and continues to be - albeit in variously differently veiled (dis)guises such as corporate neo-colonialism) the key vehicle for the exploitation of billions of oppressed and disenfranchised humans and non-humans by a small, but powerful, 'Western' elite. ${ }^{8}$ In fact, some even suggest that colonization of the Americas by this elite in the 1600s - and not the more generally accepted Industrial Revolution - is the most appropriate 'start date' of the Anthropocene:

... to use a date that coincides with colonialism in the Americas allows us to understand the current state of ecological crisis as inherently invested in a specific ideology defined by proto-capitalist logics based on extraction and accumulation through dispossession - logics that continue to shape the world we live in and that have produced our current era. ${ }^{9}$

Deeply intertwined with colonial and neo-colonial practices is the ideology of neoliberal developmentalism that has been systemically engrained into political, religious, economic and legal systems, through which it is kept alive and flourishing. As one of its staunch critics writes, neoliberal developmentalism has become 'an almost evangelical ideology of salvation through industrialisation, modernisation and integration into the global political economy through free trade and the exploitation of natural resources'. ${ }^{10}$ And today, a decade after the so-called Global Financial Crisis:

... neoliberalism lives on zombie-like, incapable of providing viable responses to either sustainability or development, but [also] seemingly incapable of being consigned to the dustbin of history ... Ecological sustainability will not be delivered by neoliberalism and it cannot be achieved through the dystopian anthropocentrism that disfigured the Holocene. ${ }^{11}$

While some commentators have reached a point of despair where they openly proclaim 'Fuck Neoliberalism', they acknowledge in the same breath that 'it is potentially quite dangerous to simply stick our heads in the sand and collectively ignore a phenomenon that has had such devastating and debilitating effects on our shared world' ${ }^{12}$

In this present issue of the Journal of Human Rights and the Environment several scholars take up the challenge to critically reflect on some of the many deeply troubling past, present and future practices of neoliberalism and colonialism within the context of the Anthropocene epoch. Their discussions contribute to interrogating the devastation that has been and is being caused by coloniality and neoliberalism in the name of 'progress' and 'development' at the expense of the vulnerable living human and non-human order. ${ }^{13}$

7. A Grear, “"Anthropocene, Capitalocene, Chthulucene": Re-encountering Environmental Law and its "Subject" with Haraway and New Materialism' in L Kotzé (ed), Environmental Law and Governance for the Anthropocene (Hart, Oxford 2017) 83.

8. A Quijano, 'Coloniality and Modernity/Rationality' (2007) 21(2-3) Cultural Studies 168-78. 9. H Davis and Z Todd, 'On the Importance of a Date, or Decolonizing the Anthropocene' (2017) 16(4) ACME: An International Journal for Critical Geographies 761-80 at 764.

10. S Adelman, 'The Sustainable Development Goals, Anthropocentrism and Neoliberalism' in D French and L Kotzé (eds), Sustainable Development Goals: Law, Theory and Implementation (Edward Elgar, Cheltenham 2018) 18.

11. Ibid at 27.

12. S Springer, 'Fuck Neoliberalism' (2016) 15(2) ACME: An International Journal for Critical Geographies 285-92 at 285.

13. A Grear, 'The Vulnerable Living Order: Human Rights and the Environment in a Critical and Philosophical Perspective' (2011) 2(1) Journal of Human Rights and the Environment 23-44. 
In 'Colonialism in the Anthropocene: the political ecology of the money-energytechnology complex', Alf Hornborg argues that Anthropocene discourse has: (i) strengthened environmental arguments and legitimized public environmental concerns in general through the popularization of terms such as 'sustainability'; (ii) challenged the conventional distinction between Society and Nature, while encouraging scholars to endorse the view that the categories 'society' and 'nature' are obsolete; (iii) suggested that humans are a unique form of life, while questioning which uniquely human features have propelled the kinds of activities that are transforming the Earth system; and (iv) highlighted the relation between environmental change and inequality - which ultimately raises concerns around human rights, equality and justice. Hornborg is particularly concerned with the question of how to reconceptualize the relation between human social organization and global ecology. Linking colonialism, neoliberal development and a key proposed onset date of the Anthropocene, Hornborg shows how the development of steam power during the Industrial Revolution in support of the British textile industry led to a deeply inequitable global social system operationalized through the trans-Atlantic slave trade, the colonization of foreign land and the exploitation of foreign labour for cotton production. He exposes the technologically mediated exploitation enacted by the Industrial Revolution, arguing that '[a]lthough locally perceived as morally and politically innocent "progress", from a global perspective the Industrial Revolution instead assumes the appearance of an asymmetric exchange of embodied labour time and a massive environmental load displacement'. Modern technology is therefore not simply a matter of pure ingenuity. It is also an exploitive colonial 'social strategy of appropriation (of labour and land), which is tantamount to saying that it is a strategy of displacement (of work and environmental loads)'. Critically reflecting on a range of environmental, climate and energy injustices being committed against vulnerable people in the name of neoliberal progress, Hornborg argues that all these global injustices of the Anthropocene 'can only be made visible by applying truly interdisciplinary perspectives that combine insights on both nature and society, while keeping the two aspects analytically distinct and refraining from the urge to reduce the natural to the social or vice versa'.

Mary Warnock, in 'Loyalty to the planet: a matter of justice or of love?', reflects upon the concept of 'loyalty to the planet' and whether such 'loyalty' could be considered a matter of justice. In doing so, she asks what difference would it make, if any at all, if we were to think of the inequality occasioned by planetary damage, and of the causation of such damage, not as a matter of unfairness, but as a matter of injustice? To describe planetary harm as being just or unjust is stronger, she believes, and is more compelling, than to describe it 'merely' as being fair or unfair. This is an understanding which at once also places such planetary harm firmly within the realm of rights, thus enabling one to ask questions such as: if a failure to control practices that harm the planet is a matter of injustice, and thus the violation of a right, what difference will this make to our future behaviour? Yet, important as human rights and their accompanying discourse of justice are, and should remain in the context of environmental protection, Warnock, in moving from the radical interiority of Descartes towards the public nature of language, suggests that it is quite possible to feel loyalty to the planet, "with only a little stretching of the usual meaning of the word'. Warnock focuses on the 'sense of belonging' that founds loyalty, arguing that it is possible to say 'I belong to the planet Earth' - which is more than a matter of belonging to a group. It is a case of belonging to the planet as a whole, in the sense of 'everything, animate and inanimate that is in, or on, it'. This, she suggests, is not a matter of human choosing - but of 
chance: we belong to the planet; it does not belong to us - and, in the final analysis, argues Warnock, 'loyalty to the planet' is more a matter of love than of justice.

In 'The idea of (climate) justice, neoliberalism and the Talanoa Dialogue', Rosemary Lyster highlights the myriad social, political, economic and juridical challenges that climate change (one of the key and arguably most popularized signatures of the Anthropocene) presents to the world. While states have managed to craft a half-hearted juridical response to climate change in the form of the Paris Climate Agreement, Lyster argues that this Agreement is in fact a neoliberal document that undermines the corrective and distributive ideals of climate justice. Relying on the capabilities approach and a modified version of Amartya Sen's The Idea of Justice ${ }^{14}$ Lyster reveals the deep tensions between neoliberalism and climate justice. Such tensions are evident she says in, for example, directly opposing beliefs that on the one hand, climate justice demands deliberative, democratic, participative and effective state-based responses to address the impacts of climate change, while on the other hand, neoliberalism relegates the role of the State to the periphery of concern, arguing as it does that the state is too large and too complex, and that regulatory activities unnecessarily disrupt the efficient operation of the market economy. Moreover, and perhaps more worryingly, she argues that neoliberalism stands accused of resulting in de-democratization: 'it renders the global South even more vulnerable and less resilient in the face of climate change, and even presents barriers to effective adaptation and adaptive capacity'. In the final analysis, Lyster embarks on an exploration of the Paris Agreement in search of John Dryzek's ideas of a 'justice-based normative meta-consensus' and a 'discursive metaconsensus', ${ }^{15}$ which he suggests must be discovered to resolve the weaknesses in Amartya Sen's The Idea of Justice. Lyster asks, in particular, whether the Paris Agreement's temperature goal constitutes a justice-based normative meta-consensus and whether the Talanoa Dialogue could be welcomed as just such a type of discursive meta-consensus.

In 'The Anthropocene, Earth system vulnerability and socio-ecological injustice in an age of human rights', Louis Kotzé seeks to initiate a debate on the continued suitability of the prevailing approach to human rights for the purpose of addressing the deepening socio-ecological injustices of the Anthropocene and to encourage exploration of alternative framings more fit for purpose in the face of the Anthropocene predicament. He argues that uncritical reliance upon the human rights paradigm as a central strategy to achieve socio-ecological justice has failed meaningfully to address the plights of many oppressed human and non-human beings, despite many human rights 'victories'. Conceptually, the human rights framework seems ill-suited for the epistemic, material and ontological demands of the Anthropocene. Because the Anthropocene predicament makes clear the vulnerability of the living order, Kotzé suggests that a re-imagination of human rights could be accomplished by utilizing vulnerability theory as an emerging epistemic framework and embodied post-identity approach with the potential to inform an ontological change of stance. Such a shift would mean moving away from a human-centred, neoliberal, Western understanding of human rights towards an understanding of the vulnerability of the entire living order as a starting point from which to critique the epistemological closures and regulatory failures of the current human rights paradigm.

14. A Sen, The Idea of Justice (Penguin Books, New York 2009).

15. JS Dryzek, 'The Deliberative Democrat's Idea of Justice' (2013) 12(4) European Journal of Political Theory 329-46. 
In 'Personhood, jurisdiction and injustice: law, colonialities and the global order', Elena Blanco and Anna Grear offer a critical reading of personhood and jurisdiction set against the stark contrast in the globalized juridical order between transnational corporations and displaced human beings. Blanco and Grear set their analysis against a concern with, on the one hand, the privilege of transnational corporations, and, on the other hand, the many barriers and exclusions facing marginalized, corporeally specific human beings, such as climate migrants. Noting that while transnational corporations are 'highly mutable, mobile agents of the global order', the authors observe that in several countries all over the world, walls and barriers are being erected to deter the movement of human beings in search of better livelihoods in 'an age of walls'. With an eye to law's entanglement in the order of meaning producing such contrasts and related injustices, the authors explore how historically deep, and ever-deepening, levels of human vulnerability are related to neoliberal globalization, while tracing the antecedents of contemporary injustices in 'uneven distributions of life and death [visible] in patterns of capitalist coloniality [and] reflected in the industrialization and plunder intensifying the trajectory towards the Anthropocene'. Set against a fundamentally decolonial reading of 'global unevenness', Blanco and Grear explore in considerable detail the idea that the mechanisms of personhood and jurisdiction operate in favour of corporate capital at both structural and ideological levels while continuing to disadvantage marginalized, corporeally specific human beings - in short, as legal techniques of privilege and predation.

Returning the focus to a more localized experience while highlighting the vagaries and destructive legacies of colonialism in relation to indigenous people, environmental destruction and human rights abuses, Maria Bargh and Estair van Wagner reflect on the ever-pervasive issue of land and natural resources that lies at the heart of many conflicts between Indigenous peoples and Settlers in settler-colonial nations. In 'Participation as exclusion: Māori engagement with the Crown Minerals Act 1991 Block Offer process', Bargh and Wagner focus their discussion around the 'coloniality of natural resource law', and particularly, on New Zealand's Crown Minerals Act 1991 Block Offer process and its attendant annual tender process for mineral prospecting and exploration. Through this process, the New Zealand government regulates the access to and ownership and extraction of minerals by offering up large areas of land to commercial tender for mineral exploration. The authors show how this law succeeds in effectively separating the Block Offer arrangements from the activities around actual mining, notably with respect to social and environmental impacts, and how the process 'privileges proponents who are presumptively entitled to develop any minerals discovered; and, subsumes questions about whether to develop minerals into questions of how development will proceed'. While there is often strong Māori participation in the Block Offer process, the authors' findings point to a more exclusionary reality whereby 'Māori views rarely influence the substantive outcomes of mineral exploration decisions'. Moreover, there is evidence, Bargh and Wagner suggest, which indicates that law and policy are used precisely in order to structure hierarchical relations in relation to land and resource use.

Finally, the issue closes with two book reviews of handbooks about research methods in environmental law and human rights law respectively. These reviews foreground the diverse range of methodological tools currently employed in both these fields as well as the need for critical reflections on methods. By publishing these together, we highlight the need for interdisciplinary dialogue, reflectivity and 'collaborative, 
6 Journal of Human Rights and the Environment, Vol. 10 No. 1

relational and thoughtful ${ }^{16}$ approaches in order to respond critically and ethically to the challenges of the Anthropocene.

Louis J. Kotzé

Research Professor of Law, Faculty of Law, North-West University, South Africa

16. McNeilly, below p. 148. 